\title{
Molecular Cloning and Phylogenetic Analysis of Two Plant-Parasitic Nematode 14-3-3 Genes
}

\author{
Dandan Liu, Lijie Chen \& Yuxi Duan (Corresponding author) \\ Nematology Institute of Northern China, Department of Plant Protection \\ Shenyang Agricultural University, Shenyang 110161, Liaoning, China \\ E-mail: liudandan.553@163.com,duanyx6407@163.com
}

Received: January 4, 2011 Accepted: January 21, $2011 \quad$ Published: December 1, 2011

doi:10.5539/jas.v3n4p86

URL: http://dx.doi.org/10.5539/jas.v3n4p86

This work is supported by Special Fund for Agroscientific Research in the Public Interest (200903030) and the earmarked fund for Modern Agro-industry Technology Research System, China.

\begin{abstract}
Full-length cDNA sequences of highly conserved ubiquitous 14-3-3 proteins were cloned from plant parasitic Heterodera glycines and Meloidogyne incognita using RT-PCR and RACE methods. The two genes were named as $\mathrm{Hgly} 2$ and Minc3, respectively. Hgly2 consisted of nucleotide sequence of $1027 \mathrm{bp}$ and Minc 3 of $1525 \mathrm{bp}$. And the open reading frames (ORF) encode peptide of 251 and 261 amino acids separately. Homology analysis showed that the deduced amino acid sequences shared the high homology with different nematode species. The phylogenetic analysis indicated that the proteins from plant parasitic nematode were more similar to insect proteins than plant and other animal proteins reported by previous research.
\end{abstract}

Keywords: Heterodera glycines, Meloidogyne incognita, 14-3-3 proteins gene, Race, Phylogenetic analysis

\section{Introduction}

A highly conserved family of regulatory proteins formed by 14-3-3 proteins is seemed to be specific to eukaryotic organisms (Fu et al., 2000; Jaubert et al., 2004). The 14-3-3 monomers have a molecular weight of approximately $30 \mathrm{kDa}$ and an isoelectric point of about 5, but functional 14-3-3 exists as a dimmer (Wang and Shakes, 1996). First identified in a survey of mammalian brain proteins, 14-3-3 proteins were named on the basis of their separation properties in two-dimensional DEAE-cellulose chromatography and starch gel electrophoresis (Moore and Perez, 1967). 14-3-3 proteins putatively participate in many vital movements. For example, they may be central to integrating the regulation of biosynthetic metabolism, cell proliferation, survival, and other processes in human cells (Rubio et al., 2004). Drosophila 14-3-3 proteins have been shown to function in RAS/MAP kinase pathways that influence the differentiation of the adult eye and the embryo even regulation the entry into mitosis in the undisturbed cell cycle. These proteins also function in normal cell cycle progression, in addition to checkpoint regulation (Su et al., 2001). Moreover in C. elegans, 14-3-3 proteins were reported as interacting proteins of a major life span regulator. They could regulate life span and possibly provide the missing link to connect two well known signaling pathways that control longevity: insulin/IGF-1 and caloric restriction (Wang et al., 2006; Araiz and Château, 2008). Then another research indicated that 14-3-3 proteins binds to and regulates DAF-16 by sequestering it in the cytoplasm (DAF-16 was another important life span regulator in the insulin/IGF-1 signaling pathway). And the mechanism was similar to the regulation has been reported in mammalian cells (Li et al., 2007). 14-3-3 gene even plays a crucial role in the early events leading to polarization of the C. elegans zygote (Morton et al., 2002).

Study in the plant-nematode interaction, 14-3-3 proteins are thought to be pathogenicity factors involved in the invasion of the root tissue and in the induction and maintenance of feeding cells (Klink et al., 2009). A 14-3-3 protein was isolated through direct qualitative analysis of proteins secreted from M. incognita J2 (Jaubert et al., 2002). Next year, 14-3-3 protein was found in the oesophageal glands of second stage juveniles (Abad et al., 2003). In 2008, 486 proteins were identified from M. incognita secretome include 14-3-3 (Bellafiore et al., 2008). In addition 14-3-3 proteins can bind to and affect a wide variety of plant proteins, such as chaperones that 
prevent proteolysis; adaptors for mediating interactions between proteins; regulators of intracellular protein distribution and transcriptional regulators (Davis et al., 2009). Hassan et al. revealed that 14-3-3 proteins may have a key role in co-ordination of mitosis, metabolism, stress response and organelle trafficking as the feeding site develops (Hassan et al., 2010).

The interaction between the nematode and its host plant has been concerned for several decades, especially in damage severely plant-parasite nematode. Here we researched two plant parasite nematode 14-3-3 genes, would lead to a better understanding of the molecular events and regulatory mechanisms involved in plant parasitism and allow the development of target-specific strategies to limit crop damage by these pathogens.

\section{Materials and Methods}

\subsection{Collection of nematode}

The nematodes were reared by their host plants in sunlight greenhouse. Cysts of $H$. glycines and oocysts of $M$. incognita incubated at $25^{\circ} \mathrm{C}$ in the laboratory as described by Nitao et al. (1999). Suspension (including J2 hatched in $24 \mathrm{~h}$ ) was collected into Eppendorf tubes, and then centrifuged at $12000 \mathrm{rpm}, 15 \mathrm{~min}$. Repetition until the weight up to $100 \mathrm{mg}$, immersed in liquid nitrogen immediately. J2 were stored at $-75^{\circ} \mathrm{C}$ until further use.

\subsection{RNA extraction and cDNA synthesis}

Total RNA was extracted from the frozen materials by RNAiso Plus (TaKaRa, China) following the manufacturer's instructions. The RNA was treated by an RNase-free DNase I for eliminating the residual genomic DNA present in our preparation. The quality of RNA was tested by $1 \%(\mathrm{w} / \mathrm{v})$ agarose gel electrophoresis. The first-strand cDNA for reverse transcriptional PCR (RT-PCR) was synthesized by following 3'-Full RACE Core Set Ver.2.0 (TaKaRa, China) with 3.5 $\mu \mathrm{L}$ of total RNA as the template.

\subsection{Internal amplification}

2 pairs of Gene-specific primer (GSP) for amplification H. glycines and M. incognita 14-3-3 proteins gene were designed by primer 5.0 .

Hgly2-1: 5'-GCGTTCGATGATGCGATTGCTG-3',

Hgly2-2: 5'-ATTTACCCAATCAAAAGTGCC-3'.

Minc 3-1: 5'-TCTTGGCGTGTTCTTTCGTCTAT-3',

Minc3-2: 5'-AAAAGACTGCTTAGCCAACTGAC-3'.

Both reactions were performed with $50 \mu \mathrm{L}$ reaction mixture containing $2 \mu \mathrm{L}$ single-stranded cDNA, $8 \mu \mathrm{L} 1 \times$ cDNA Dilution Buffer II, $2 \mu \mathrm{L}$ of each primer $(10 \mathrm{uM}), 25 \mu \mathrm{L} 2 \times$ GC Buffer, $0.5 \mu \mathrm{L}$ Tag polymerase $(5 \mathrm{U} / \mu \mathrm{L})$, $10.5 \mu \mathrm{L} \mathrm{dH}{ }_{2} \mathrm{O}$. The condition for amplification of cDNA segments were $94^{\circ} \mathrm{C}$ for $3 \mathrm{~min}, 30$ cycles at $94^{\circ} \mathrm{C}$ for 30 $\mathrm{s}, 55^{\circ} \mathrm{C}$ for $30 \mathrm{~s}, 72^{\circ} \mathrm{C}$ for $30 \mathrm{~s}$ then $72^{\circ} \mathrm{C}$ for $10 \mathrm{~min}$.

\section{$2.4 R A C E$}

In order to obtain the full-length transcript, a rapid amplification of cDNA ends (RACE) procedure was employed to amplify the $5^{\prime}$ and $3^{\prime}$ end of the coding region according to the instructions (5'-Full RACE Kit and 3'-Full RACE Core Set Ver.2.0, TaKaRa, China). The full-length cDNA sequences from $H$. glycines and $M$. incognita were named as Hgly2 and Minc3. In H. glycines, 5'RACE GSP primers Hgly2-3: 5'-TCGGATGTCCAAAGCGTCAAG-3'was applied in outer PCR and Hgly2-4: 5'-GTCCAGCTCAGCAATCGCATC-3' in inner PCR. 3'RACE GSP primers were Hgly2-1 (outer PCR): 5'-GCGTTCGATGATGCGATTGCTG-3' and Hgly2-5 (inner PCR): 5'-CTGGCGATGAGCAGGAGG-3'. In $M$. incognita, the GSP primers of 5'RACE were Minc3- 3 (outer PCR): 5'-AACACGCCAAGAAGAACGAC-3' and Minc3-4(inner PCR): 5'-TCAGCCTGTTCGGCGAGTTTGG-3'. Minc3-5: 5'-ATCGTTATTTGGCTGAGGTTTC-3'used with outer primer and Minc3-6: 5'-CACAACAGAGTTACCAAGAGGC-3' used with inner primer in 3'RACE. The PCR products were electrophoresed on $1 \%(\mathrm{w} / \mathrm{v})$ agarose gel.

A blast search was completed in NCBIBLAST network server (http://blast.ncbi.nlm.nih.gov/ BLAST.cgi). Deduced amino acid sequences were aligned using DNAstar software. Subcellular localization by SignalP 3.0 Servere (www.cbs.etu.dk/services/signalp) and proteins analysis in ExPASy: ScanProsite tool (http://www.expasy.ch/tools/scanprosite). Alignment and phylogenetic analysis were performed using the software MEGA 4.1 and Clustal X. 


\section{Results}

\subsection{Sequence analysis}

The cDNA fragments of $338 \mathrm{bp}$ from $H$. glycines and $411 \mathrm{bp}$ from $M$. incognita were attained by RT-PCR approach. The RACE procedure was further employed to obtain full-length sequences of the two genes. And results showed that cDNA clone encoding $\mathrm{Hgly2}$ was $1027 \mathrm{bp}$ with an open reading frame for a polypeptide of 251 amino acids (Fig.1) and a molecular mass of $28.47 \mathrm{kD}$. The cDNA clone encoding Minc 3 was 1525 bp with 261 amino (Fig.2) acids and a molecular mass of $29.41 \mathrm{kD}$. The isoelectric point ( $p \mathrm{I})$ of Hgly2 was 4.48 and Minc3 was 4.36. Both Hgly2 and Minc3 have 14-3-3 gene family conserved regions (Fig.3). In addition no signal peptide and transmembrane regions were found.

Further, Subcellular localization and ScanProsite revealed that Hgly2 and Minc3 possibility be found in cytoplasmic, nuclear, cytoskeletal, mitochondrial, golgi, endoplasmic and plasma membrane. Hgly2 was predicted possession 4 protein kinase C phosphrylation sites, 2 cAMP-and cGMP-dependent protein kinase phosphorylation sites, $5 \mathrm{~N}$-myristoylation sites, 7 casein kinase II phosporylation sites, 1 Tyrosine kinase phosphorylation site and $2 \mathrm{~N}$-glycosylation sites. Minc 3 potentially hold 9 casein kinase II phosporylation sites, 3 protein kinase $\mathrm{C}$ phosphrylation sites, 2 cAMP-and cGMP-dependent protein kinase phosphorylation sites, 4 $\mathrm{N}$-myristoylation sites, 1 Amidation site, 1 Tyrosine kinase phosphorylation site and $1 \mathrm{~N}$-glycosylation site.

\subsection{Homology analysis}

The full amino acid sequences we got were aligned with other species (Fig.4). We found that Hgly2 share $82.46 \%$ identity with Minc3; 94.76\% with Bursaphelenchus xylophilus (GU130158.1); 93.59\% with Caenorhabditis brenneri (EU726795.1); 93.59\% with Caenorhabditis remanei (XM_003109679.1); 87.45\% with Culex pipiens (GU227357.1); 88.09\% with Drosophila melanogaster (NM_165740.2); 70.69\% with Rattus norvegicus (BC089860.1) and 81.97\% with Homo sapiens (NM_003404.3).

While Minc3 identity to B. xylophilus was $82.74 \%$; C. brenneri, $82.89 \%$; C. remanei, $82.89 \%$; C. pipiens, $87.45 \%$; D. melanogaster, $88.09 \%$; R. norvegicus, $70.69 \%$ and Homo sapiens, $81.97 \%$.

Comparison of protein sequences was also revealed that the $\mathrm{N}$ terminal 10 amino acids and the $\mathrm{C}$ terminal 20 amino acids showed more varariations than the other parts, indicating that these amino acids may be responsible for the isoform specificities.

\subsection{Phylogenetic analysis}

Based on the deduced amino acid sequences, a phylogenetic tree was constructed (Fig.5). All the sequences used in our analysis got from NCBI but 14-3-3 proteins from Entamoeba histolytic were approved distant related (Wang and Shakes, 1996) and other protozoa not employed. 14-3-3 proteins from 24 species could be divided into 4 groups through the comparison. Nematode proteins except Trichinella spiralis were clustered together and appeared to be more closely to insect, distantly to animal. T. spiralis was a human parasite more similar to insect than plant parasite nematode. The plant lineage formed a distinct grouping in N-J trees, suggested an early divergence from the other species. Invertebrate proteins group including nematode and insect with the nonepsil on mammalian and the result basically consisted with former research (Wang and Shakes, 1996).

\section{Discussion}

Protein 14-3-3 was also named tyrosine 3-monooxygenase/tryptophan 5-monooxygenase activation protein. Since first reported about 14-3-3 proteins, the researchers have done a lot of work in animal and human parasite (Siles-Lucas et al., 2003; Joshua et al., 2009) but on the contrary for plant parasite nematodes. We know $H$. glycines and M. incognita were two important pathogens for crops and vegetables in the world. As early as 1987, Meloidogyne spp. was reported responsible for a large part of the annual 100 billion $\$$ losses attributed to nematode damage in US (Sasser et al., 1987). Soybean cyst nematode suppressed US soybean yield more than any other disease during 2003 to 2005, soybean yield suppression was 2.9 million ton in 2003 and 1.9 million ton in 2005 (Wrather and Koenning, 2006). Unfortunately we hadn't high efficiency and environmental friendly control methods presented due to nematodes body was extremely small, physiology and metabolism almost incomprehension for us.

Protein 14-3-3 was speculated to participate in the process nematode infect host plant. And two14-3-3 isoforms isolated from M. incognita infective larvae (Jaubert et al., 2004; Curtis, 2007; Dubreuil et al., 2007) maybe involve in infection. Expression 14-3-3 gene in $H$. schachtii has also been localized within genital primordia of infective J2 (De et al., 2001). And we could obtain the partial sequences of H. glycines 14-3-3 gene from NCBI (article unpublished) and the full long still not reported. In our study we cloned the full cDNA sequence of 
14-3-3 gene from $H$. glycines and $M$. incognita further alignment amino acid sequences, the results showed that the sequence of $H$. glycines 14-3-3 gene was $100 \%$ homology with the fragment in GenBank (GenBank: AF402309.1) and $M$. incognita 14-3-3 gene was $97 \%$ similar to that previously reported (GenBank: AF070225.1).

The ubiquity of 14-3-3 gene was validated again by our subcellular localization analysis. Multiple sequence alignment and phylogenetic analysis showed 14-3-3 genes were the highly conserved this result was consistent with former research. We supposed the functions of these proteins be conserved between plants and nematodes. The important function was phosphatases. The 14-3-3 proteins bound to a wide array of target proteins and then modulation many proteins involved in phosphatases and protein kinases (Yaffe et al., 1997; Masters et al., 1999; Sehnke et al., 2002). Other functions of 14-3-3 proteins also reported. For example, cell regulatory pathways, including signal transduction, apoptosis, stress response and transformation, could be targeted by one or several 14-3-3 gene isoform products in organisms ranging from yeast to human (Finnie et al., 1999; Van Hemert et al., 2001).

Therefore studies on these highly conserved proteins may allow novel strategies of plant-parasite nematode control. Maybe a potential strategy by interfering with the expression of 14-3-3 genes would be used to control the two nematodes.

\section{References}

Abad, P., Favery, B., Rosso, M-N., \& Castagnone-Sereno, P. (2003). Root-knot nematode parasitism and host response: molecular basis of a sophisticated interaction. Molecular Plant Pathology, 4, 217-224. http://dx.doi.org/10.1046/j.1364-3703.2003.00170.x

Araiz, C., Château, M-T., \& Galas, S. (2008). 14-3-3 regulates life span by both DAF-16-dependent and -independent mechanisms in Caenorhabditis elegans. Experimental Gerontology, 43, 505-519. http://dx.doi.org/10.1016/j.exger.2008.03.001

Bellafiore, S., Shen, Z., Rosso, M-N., Abad, P., Shih, P., \& Briggs, S. P. (2008). Direct identification of the Meloidogyne incognita secretome reveals proteins with host cell reprogramming potential. PLoS Pathogens, 4, 1-12. http://dx.doi.org/10.1371/journal.ppat.1000192

Curtis, R. H. C. (2007). Plant parasitic nematode proteins and the host-parasite interaction. Briefings in Functional Genomics and Proteomics, 6, 50-58. http://dx.doi.org/10.1093/bfgp/elm006

Davis, E. L., Hussey, R. S., \& Baum, T. J. (2009). Parasitism genes: what they reveal about parasitism. Plant Cell Monographs, 15, 15-44. http://dx.doi.org/10.1007/978-3-540-85215-5_2

De, M. J., Vanholme, B., \& Bauw, G. (2001). Preparation and sequencing of secreted proteins from the pharyngeal glands of the plant parasitic nematode Heterodera schachtii. Molecular Plant Pathology, 2, 297-301. http://dx.doi.org/10.1046/j.1464-6722.2001.00078.x

Dubreuil, G., Magliano, M., Deleury, E., Abad, P., \& Rosso, M. N. (2007). Transcriptome analysis of root-knot nematode functions induced in the early stages of parasitism. New Phytologist, 176, 426-436. http://dx.doi.org/10.1111/j.1469-8137.2007.02181.x

Finnie, C., Borch, J., \& Collinge, D. B. (1999). 14-3-3 proteins: eukaryotic regulatory proteins with many functions. Plant Molecular Biology, 40, 545-554. http://dx.doi.org/10.1023/A:1006211014713

Fu, H., Subramanian, R. R., \& Masters, S. C. (2000). 14-3-3 Proteins Structure, Function, and Regulation. $\begin{array}{lllll}\text { Annual Review of Pharmacology and Toxicology, 40, 617-647. } & \end{array}$ http://dx.doi.org/10.1146/annurev.pharmtox.40.1.617

Hassan, S., Behm, C. A., \& Mathesius, U. (2010). Effectors of plant parasitic nematodes that re-program root cell development. Functional Plant Biology, 37, 933-942. http://dx.doi.org/10.1071/FP10112

Jaubert, S., Laffaire, J-B., Ledger, T. N., Escoubas, P., Amri, E-Z., Abad, P., \& Rosso, M. N. (2004). Comparative analysis of two 14-3-3 homologues and their expression pattern in the root-knot nematode Meloidogyne incognita. International Journal for Parasitology, 34, 873-880. http://dx.doi.org/10.1016/j.ijpara.2004.02.008

Jaubert, S., Ledger, T. N., Laffaire, J. B., Piotte, C., Abad, P., \& Rosso, M. N. (2002). Direct identification of stylet secreted proteins from root-knot nematodes by a proteomic approach. Molecular \& Biochemical Parasitology, 121, 205-211. http://dx.doi.org/10.1016/S0166-6851(02)00034-8

Joshua, E. K., Gao, X., Krepp, J. M. \& Hawdon, J. M. (2009). Interaction of hookworm 14-3-3 with the forkhead 
transcription factor DAF-16 requires intact Akt phosphorylation sites. Parasites \& Vectors, 2, 21-34. http://dx.doi.org/10.1186/1756-3305-2-21

Klink, V. P., Kim, K-H., Martins, V., MacDonald, M. H., Beard, H. S., Alkharouf, N. W., Lee, S-K., Park, S-C., $\&$ Matthews, B. F. (2009). A correlation between host-mediated expression of parasite genes as tandem inverted repeats and abrogation of development of female Heterodera glycines cyst formation during infection of Glycine max. Planta, 230, 53-71. http://dx.doi.org/10.1007/s00425-009-0926-2

Li, J., Tewari, M., Vidal, M., \& Lee, S. S. (2007). The 14-3-3 protein FTT-2 regulates DAF-16 in Caenorhabditis elegans. Developmental Biology, 301, 82-91. http://dx.doi.org/10.1016/j.ydbio.2006.10.013

Masters, S. C., Pederson, K. J., Zhang, L., Barbieri, J. T., \& Fu, H. (1999). Interaction of 14-3-3 with a nonphosphorylated protein ligand, exoenzyme S of Pseudomonas aeruginosa. Biochemistry, 38, 5216-5221. http://dx.doi.org/10.1021/bi982492m

Moore, B.W., \& Perez, V. J. (1967). Specific acidic proteins of the nervous system. In F. D. Carlson (Ed.), Physiological and biochemical aspects of nervous integration (pp. 343-359). Woods Hole: Prentice Hall Inc.

Morton, D. G., Shakes, D. C., Nugent, S., Dichoso, D., Wang, W., Golden, A., \& Kemphues, K. J. (2002). The Caenorhabditis elegans par-5 gene encodes a 14-3-3 protein required for cellular asymmetry in the early embryo. Developmental Biology, 241, 47-58. http://dx.doi.org/10.1006/dbio.2001.0489

Nitao, J. K., Meyer, S. L. F., \& Chitwood, D. J. (1999). In-vitro assays of Meloidogyne incognita and Heterodera glycines for detection of nematode-antagonistic fungal compounds. Journal of Nematology, 31, 172-183.

Rubio, P. M., Geraghty, K. M., Wong, B. H. C., Wood, N. T., Campbell, D. G., Morrice, N. \& Mackintosh, C. (2004). 14-3-3-affinity purification of over 200 human phosphoproteins reveals new links to regulation of cellular metabolism, proliferation and trafficking. Journal of Biochemistry, 379, 395-408. http://dx.doi.org/10.1042/BJ20031797

Sasser, J. N., Hartman, K. M., \& Carter, C. C. (1987). Summary of preliminary crop germplasm evaluation for resistance to root- knot nematodes. Raleigh, NC: North Carolina State University and US Agency for International Development, 1-88.

Sehnke, P. C., DeLille, J. M., \& Ferl, R. J. (2002). Consummating signal transduction: the role of 14-3-3 proteins in the completion of signal-induced transitions in protein activity. The Plant Cell, 14, 339-354.

Siles-Lucas, M. M., \& Gottstein, B. (2003). The 14-3-3 protein: a key molecule in parasites as in other organisms. Trends in Parasitology, 19, 575-581. http://dx.doi.org/10.1016/j.pt.2003.10.003

Su, T. T., Parry, D. H., Donahoe, B., Chien, C-T., O'Farrell, P. H., \& Purdy, A. (2001). Cell cycle roles for two 14-3-3 proteins during Drosophila development. Journal of Cell Science, 114, 3445-3454.

Van Hemert, M. J., Steensma, H. Y., \& Van Heusden, G. P. (2001). 14-3-3 proteins: key regulators of cell division, signalling and apoptosis. Bioessays, 23, 936-946. http://dx.doi.org/10.1002/bies.1134

Wang, W., \& Shakes, D. C. (1996). Molecular evolution of the 14-3-3 protein family. Journal of Molecular Evolution, 43, 384-398. http://dx.doi.org/10.1007/BF02339012

Wang, Y., Oh, S. W., Deplancke, B., Luo, J., Walhout, A. J. M., \& Tissenbaum, H. A. (2006). C. elegans 14-3-3 proteins regulate life span and interact with SIR-2.1 and DAF-16/FOXO. Mechanisms of Ageing and Development, 127, 741-747. http://dx.doi.org/10.1016/j.mad.2006.05.005

Wrather, J. A., \& Koenning, S. R. (2006). Estimates of disease effects on soybean yields in the United States 2003 to 2005. Journal of Nematology, 38, 173-180.

Yaffe, M. B., Rittinger, K., Volinia, S., Caron, P. R., Aitken, A., Leffers, H., Gamblin, S. J., Smerdon, S. J., \& Cantley, L. C. (1997). The structural basis for 14-3-3: phosphopeptide binding specificity. Cell, 91, 961-971. http://dx.doi.org/10.1016/S0092-8674(00)80487-0 
1 ggtttaattacccaagtttgaggagaattgaaattttatcttttgaaaatcgtctagacctatttaatttttcgaaaa

79 ATG TCT GAC AAC AAA GAA GAA CTC GTT CAG GGG GCT AAG TTG GCT GAG CAA GCT GAG CGC

$\begin{array}{lllllllllllllllllllllllll}M & S & D & N & K & E & E & L & V & Q & R & A & K & L & A & E & Q & A & E & R\end{array}$

139 TAC GAT GAC ATG GCT CAG TCG ATG AAA AAG GTG ACG GAA TTG GGT GCG GAG TTG AGT AAT

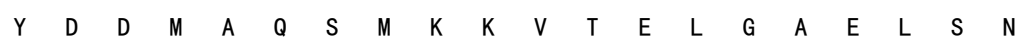

199 GAG GAG CGC AAC CTG TTG TCG GTT GCA TAC AAA AAT GTG GTC GGT GCG CGT CGT TCC TCG

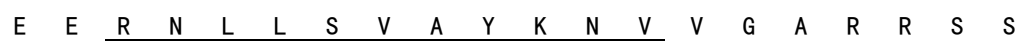

259 TGG CGC GTT ATC TCG TCC ATT GAA CAG AAG ACT GAG GGC TCG GAG AAG AAG CAG CAG ATG

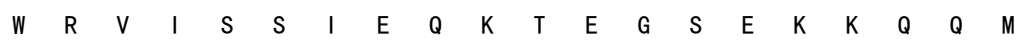

319 GCC AAG GAG TAT CGG GAG AAG GTG GAG CAG GAG TTG CGA GAG ATC TGT CAC GAC GTG CTG

$\begin{array}{lllllllllllllllllllll}A & K & E & Y & R & E & K & V & E & Q & E & L & R & E & \text { I } & C & H & D & V & L\end{array}$

379 GAT TTG CTC GAC AAA TAT CTG ATC CCG AAG GCT GGC AAC CCG GAA TCA AAG GTG TTC TAC

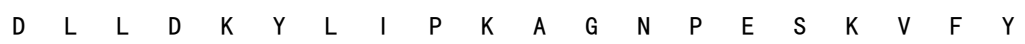

439 CTG AAG ATG AAG GGT GAC TAC TAC CGC TAC CTG GCT GAG GTT GCC ACC GGT GAC GAC CGA

$\begin{array}{lllllllllllllllllllll}L & K & M & K & G & D & Y & Y & R & Y & L & A & E & V & A & T & G & D & D & R\end{array}$

499 AAC GCT GTT GTC GAG AAG TCG CAG CAG TCG TAC CAG GAA GCG TTT GAC ATT GCC AAG GAC

$\begin{array}{lllllllllllllllllllllllllll}N & A & V & V & E & K & S & Q & Q & S & Y & Q & E & A & F & D & I & A & K & D\end{array}$

559 AAA ATG CAG CCC ACC CAT CCC ATT CGT CTT GGT CTG GCG CTG AAC TTC TCT GTG TTC TAC

$\begin{array}{llllllllllllllllllllll}K & M & Q & P & T & H & P & I & R & L & G & L & A & L & N & F & S & V & F & Y\end{array}$

619 TAT GAA ATT CTG AAC TCA CCG GAC AAG GCG TGC CAA CTC GCC AAA CAG GCG TTC GAT GAT

$\begin{array}{llllllllllllllllllll}\text { Y } & E & \text { I } & \text { L } & \text { N } & \text { S } & \text { P } & D & K & A & C & Q & L & A & K & Q & A & F & D & D\end{array}$

679 GCG ATT GCT GAG CTG GAC ACG CTC AAC GAG GAC TCG TAC AAG GAC TCC ACT CTG ATC ATG

\begin{tabular}{llllllllllllllllllll}
$A$ & $I$ & $A$ & $E$ & $L$ & $D$ & $T$ & $L$ & $N$ & $E$ & $D$ & $S$ & $Y$ & $K$ & $D$ & $S$ & $T$ & $L$ & $I$ & $M$ \\
\hline
\end{tabular}

739 CAA CTG TTG CGT GAC AAC TTG ACG CTT TGG ACA TCC GAC ACG GCT GGC GAT GAG CAG GAG

$\begin{array}{lllllllllllllllllllll}Q & \mathrm{~L} & \mathrm{~L} & \mathrm{R} & \mathrm{D} & \mathrm{N} & \mathrm{L} & \mathrm{T} & \mathrm{L} & \mathrm{W} & \mathrm{T} & \mathrm{S} & \mathrm{D} & \mathrm{T} & \mathrm{A} & \mathrm{G} & \mathrm{D} & \mathrm{E} & \mathrm{Q} & \mathrm{E}\end{array}$

799 GCT GGT GGT GAG GCG GGC GAA GCT GGT GGC AAC TGA

$\begin{array}{llllllllllll}A & G & G & E & A & G & E & A & G & G & N & *\end{array}$

836 tcgggcggacagacgttgaagaccaagaaaatgccccacgaaattttttccaccgaatcatttaatgacaattatgctt

914 ttctcaatatggcacttttgattgggtaaatttttttgaaaatcgttcaattaaaattgtcgtttaccagtcactctg

992 aacattaaaaattggcgtttctcaaaaaaaaaaa

Figure 1. cDNA sequence and predicted amino acids sequence of Hgly2

The lower-case characters indicate noncoding regions; the stop codon is indicated with an asterisk; the shadow areas indicates poly (A); underline sequences were proteins motif. 
ttttctcccatgtttttaatttttttaatttattgttagtatacaactgattatagtccgtagggtctagtgttattt

119 ttaaattgattttttctgtatttaagcttgacgagaagtatataatcattatcattcttctttgggttgaactttg

tgatttttatttgtgtccgaaatgtcccacatgtccgaaatgtcttcccttcttccgcctctcacaacgattaagaaaa

277

ggaaaagacaccttagttgttcactagacattatagatcaagctttacctcatgtcgataagtacacagctttacgcat

tagaacctattctacgcggcatgctcgtatatgccaaacatttgtggacgtgggccgataaacgcatagttccaacttc

ttccctataggtacctattatcctttctagaggattttctttgtgtttcaattcttttttattataagtttttacatca

attccccttataattatcaatttcttttatttcagtattacatattatcttcttacgcttaattttctttcaacaata

ATG ACG GAG ACA ATG TTG GAT TGC TCT GAC AAG GTG ACT GAG TCC AAG GAA GAA CTT GTT

$\begin{array}{lllllllllllllllllllll}M & T & E & T & M & L & D & C & S & D & K & V & T & E & S & K & E & E & L & V\end{array}$

653

CAG CTT GCC AAA CTC GCC GAA CAG GCT GAG CGT TAT GAT GAC ATG GCA GAG TCA ATG AAG

$\begin{array}{lllllllllllllllllllll}Q & L & A & K & L & A & E & Q & A & E & R & Y & D & D & M & A & E & S & M & K\end{array}$

713 AAG GTT ACC GAA TTT GGA GAC GAA CTG TCT AAT GAG GAG CGC AAT CTT CTC TCG GTT GCT

\begin{tabular}{llllllllllllllllllll}
$K$ & $V$ & $T$ & $E$ & $F$ & $G$ & $D$ & $E$ & $L$ & $S$ & $N$ & $E$ & $E$ & $R$ & $N$ & $L$ & $L$ & $S$ & $V$ & $A$ \\
\hline
\end{tabular}

773 TAT AAG AAT GTT GTT GGG GCT CGT CGT TCT TCT TGG CGT GTT CTT TCG TCT ATT GAG CAA $\begin{array}{lllllllllllllllllllllll}\mathrm{Y} & \mathrm{K} & \mathrm{N} & \mathrm{V} & \mathrm{V} & \mathrm{G} & \mathrm{A} & \mathrm{R} & \mathrm{R} & \mathrm{S} & \mathrm{S} & \mathrm{W} & \mathrm{R} & \mathrm{V} & \mathrm{L} & \mathrm{S} & \mathrm{S} & \mathrm{I} & \mathrm{E} & \mathrm{Q}\end{array}$

833 AAG ACC GAA GGG GGG AAG AAG ACG ATG ACT AAG GAA TAC CGT GAG AAG ATY GAR KGT GAA

$\begin{array}{llllllllllllllllllllllllllll}K & T & E & G & G & K & K & T & M & T & K & E & Y & R & E & K & I & E & X & E\end{array}$

893 TTG CGT GAC ATT TGC AAA GGK GTT ATG AAT CTT CTG GAC AAA TTT CTT ATT CCG AAA GCT

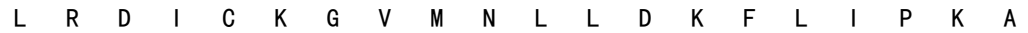

953 GGA ACT CCT GAT TCT AAA GTG TTC TAC CTT AAG ATG AAG GGC GAC TAC TAT CGT TAT TTG

$\begin{array}{lllllllllllllllllllll}G & T & P & D & S & K & V & F & Y & L & K & M & K & G & D & Y & Y & R & Y & L\end{array}$

1013 GCT GAG GTT TCT TCT GGT GAT GAG TTG ACT GAT GTT ATC GAC AAA TCA CAA CAG AGT TAC

$\begin{array}{llllllllllllllllllllll}A & E & V & S & S & G & D & E & \text { L } & T & D & V & \text { I } & \text { D } & \text { K } & \text { S } & Q & Q & S & Y\end{array}$

1073 CAA GAG GCT TTC GAT ATT GCT AAG GAC AAA ATG CCG CCA ACT CAT CCA ATT CGT CTT GGG

$\begin{array}{lllllllllllllllllllll}Q & E & A & F & D & \text { I } & A & K & D & K & M & P & P & T & H & P & I & R & L & G\end{array}$

1133 CTG GCT CTC AAC TTT TCG GTC TTC TAC TTT GAG ATT CTC GAC AAT AAG GAC AAG GCT TGT

$\begin{array}{llllllllllllllllllllllllllllll}L & A & L & N & F & S & V & F & Y & F & E & I & L & D & N & K & D & K & A & C\end{array}$

1193 CAG TTG GCT AAG CAG TCT TTT GAT GAG GCT GTT GCT GAG TTG GAC ACT CTT GAC GAG AAT

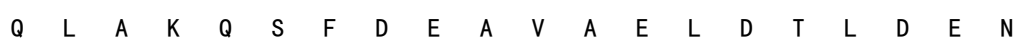

1253 TTG TAC AAG GAC TCG ACT CTC ATT ATG CAA CTT CTT CGC GAC AAT TTG ACT CTG TGG ACT

\begin{tabular}{llllllllllllllllllllll}
$\mathrm{L}$ & $\mathrm{Y}$ & $\mathrm{K}$ & $\mathrm{D}$ & $\mathrm{S}$ & $\mathrm{T}$ & $\mathrm{L}$ & $\mathrm{I}$ & $\mathrm{M}$ & $\mathrm{Q}$ & $\mathrm{L}$ & $\mathrm{L}$ & $\mathrm{R}$ & $\mathrm{D}$ & $\mathrm{N}$ & $\mathrm{L}$ & $\mathrm{T}$ & $\mathrm{L}$ & $\mathrm{W}$ & $\mathrm{T}$ \\
\hline
\end{tabular}

1313 TCC GAT GGC GGC GCT GAG GAA CCG GAG GCG GCT CCA ATT GCT GCT GAT GCC GAA GGC ACA

$\begin{array}{llllllllllllllllllllllllllllllll}S & D & G & G & A & E & E & P & E & A & A & P & I & A & A & D & A & E & G & T\end{array}$

1373 AAT TAA

$\mathrm{N} *$

1379 gtgaaggaaagtggagtaaataattaaatggtaaagaagggaaaatataaggaaagacaattttttaatttattcgagt

1458 atttgtttgtttatgattatattttgtctttcgaccatctataaaaaagttggcaaaaaaaaaaa

Figure 2. cDNA sequence and predicted amino acids sequence of Minc3

The lower-case characters indicate noncoding regions; the stop codon is indicated with an asterisk; the shadow areas indicates poly (A); underline sequences were proteins motif. 

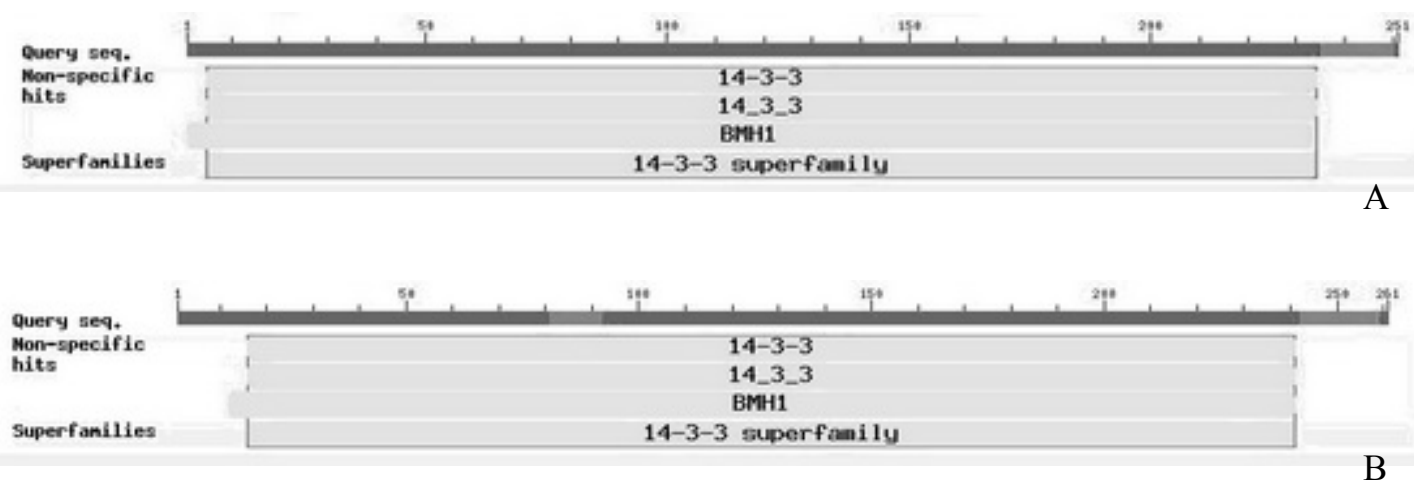

Figure 3. Conserved domains of amino acid sequences of $\operatorname{Hgly2}$ (A) and Minc3 (B)

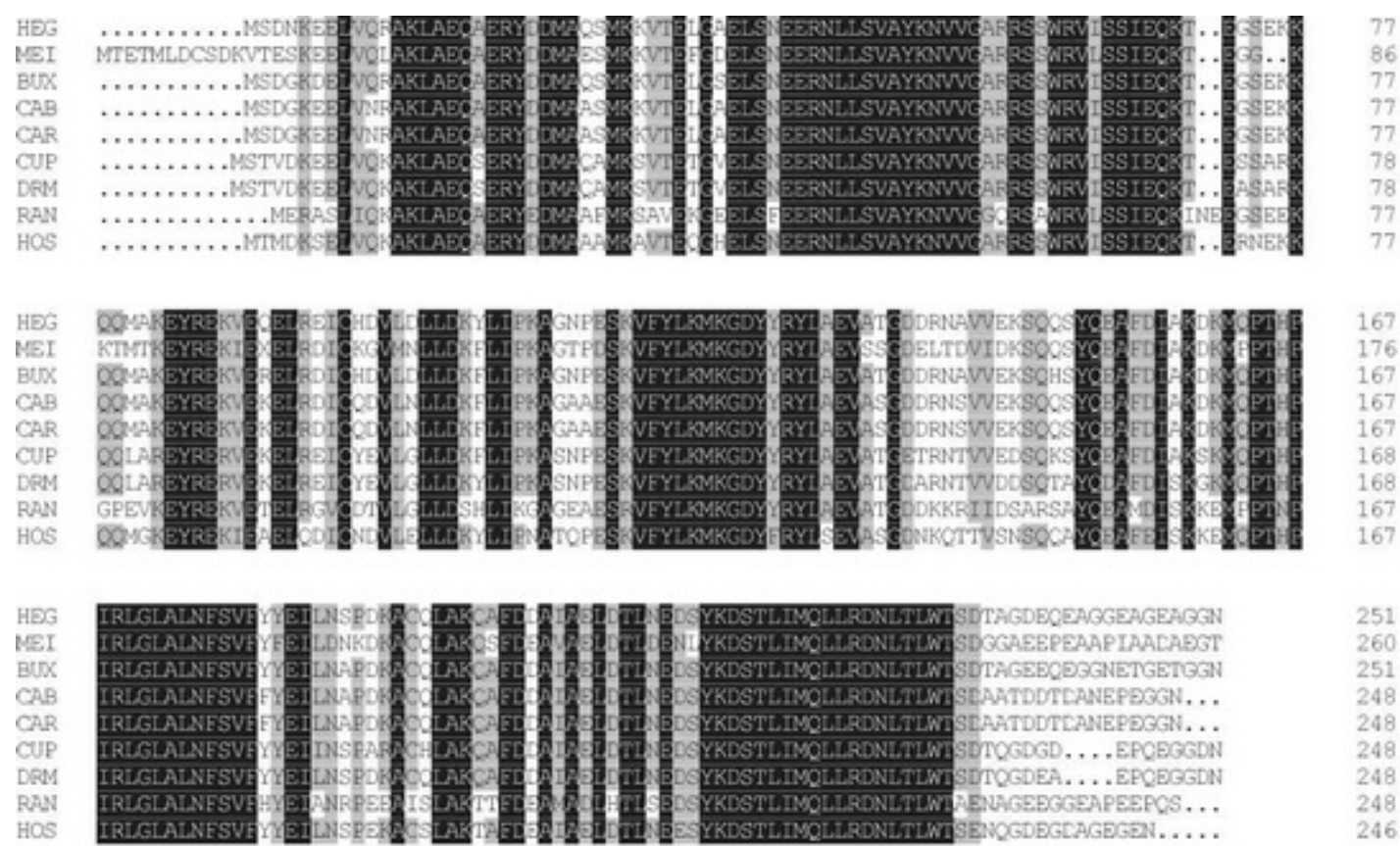

Figure 4. Alignment of deduced amino acid sequences of Hgly2 and Minc3 with other species

HEG, MEI, BUX, CAB, CAR, CUP, DRM, RAN, HOS denote14-3-3 protein from H. glycines, M. incognita, B. xylophilus, C. brenneri, C. remanei, C. pipiens, D. melanogaster, R. norvegicus, Homo sapiens respectively; Dots indicate gaps introducing to facilitate the alignment; Identical and similar amino acid residues are shaded in black and gray. 


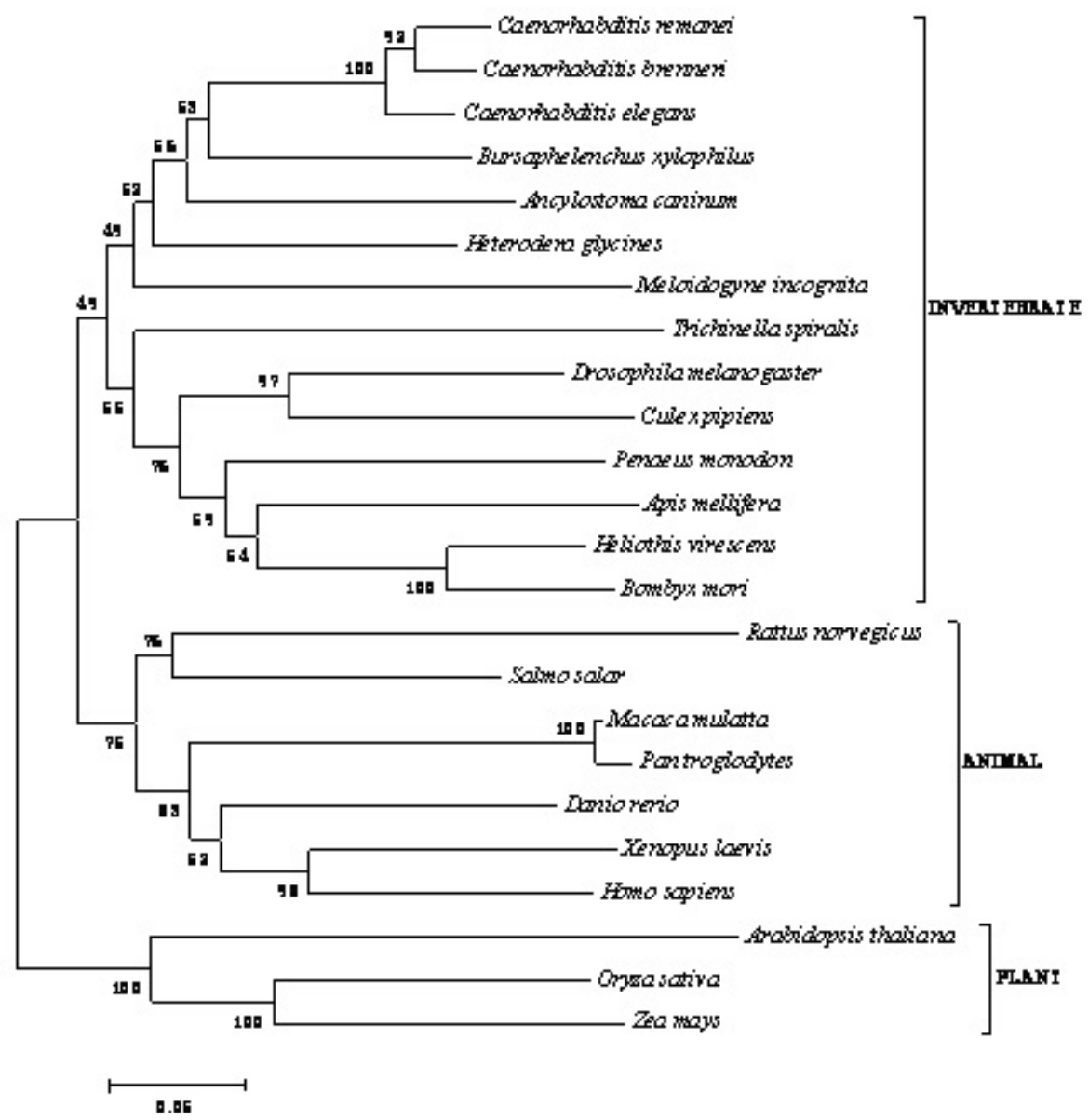

Figure 5. A phylogenetic tree analysis with $\mathrm{Hgly2}$, Minc3 and 22 species 14-3-3 proteins using Neighbor-Joining method 